\title{
The Relation between Nature and Society in an Exception Environment, Meruoca Sierra, Ceará, Brazil
}

\author{
Marcos Venicios Ribeiro Mendes \\ Masteringin Geographyat Vale do AcaraúState University (UVA). \\ Simone Ferreira Diniz \\ Prof. Dr.in the Geography Master Course at Vale do AcaraúState University \\ Cleire Lima da Costa Falcão \\ Prof. Dr.inthe Geography Courseat Ceará State University(UECE). \\ José Falcão Sobrinho \\ Prof. Dr.in the Geography Master Course at Vale do Acaraú State University (UVA).
}

\begin{abstract}
This present essay addresses the presentation of a discussion about the relation between nature and society, going from the nature concept comprehension to modifications which has been taking place in geographical space.Meruoca Sierrais held as a cutout for this research, an exception area in Ceará semi-arid which contains a natural physical framework different from the others relief units around the state. Some procedures were adopted as methodology, all of them based on literary review, starting with Ludwin von Bertalanffy's systemic approach (1975) which states that elements are a part of a whole and they must be studied jointly instead of individually. Fieldwork was also carried out for a better recognition of the area and through it was possible to notice modifications beside photographical records.Linked to these conditions there are hydric resources, fauna, flora and specially soils which has been quite exploited by the society and for this reason some samples of them were collected to be physically analyzed. From this fact, it was possible to understand modifications in nature caused by the society what reflect on an environmental imbalance in Meruoca.
\end{abstract}

Keywords: Nature, Society, Meruoca.

\section{Introduction}

It is made explicit that the word nature comes from the expression natura which means "essential quality, instinctive provision". In a wider sense, the nature correspondent to the "natural world" or "physical universe", refers to physical world phenomena, as life in general. Given its origin, it does not involve objects produced by man.

Carvalho (1991,p. 113) affirms that it is obvious that the definition or conceptualization of what is nature depends of the perception humans have of it, and therefore, of the purpose pointed to it, that is, stems from forms and goals of social routine. However, there have been a lot of definitions in various societies constituted by man over the years.

In keeping with that line of reasoning, Silva (2019, p.16) shows in his judgment that the concept of nature has been approached and discussed "along the histories of science and humanity, this last which has undergone repeated paradigmatic modifications in accordance to interaction conditions between man and environment in the construction and restoration process of social or humanized spaces".

This time, the understanding about the science of nature has happened through the conception of topics displayed along philosophy history and approached by many philosophers, namely Platão, Aristoteles, Agostinho, Tomás de Aquino, Descartes, Hobbes, Locke, Hume, Rousseau, Kant, Hegel, Marx, Nietzsche, Wittgenstein, Heidegger(FALCÃO SOBRINHO;COSTA FALCÃO, 2008).

From that assumption, studies about nature and others related topics have been largely explained in the scientific field. Due to this thinking, as regards sciences, there is geographical science, which has as main study object the relation between man and nature in a certain space. Hence, since the birth of such science (geography) and with its distribution in two branches (physical and human), discussions towards nature and its relationship with society has been continual. In this view, Silva and Corrêa (2009, p. 111) reveal in their speeches that "this is a trend which aims to analyze the relation man-environment and tries to combine what is called physical geography studies with human geography components, or vice-versa. This way, it is made possible that scholars plunge into discussions about the understanding of relationships present between man and nature. 
In this sense, man starts to develop technological methods only long after his development and,facing such situation, it is seen the first processes of man and nature, or natural environment. This natural environmentoriginates from the dawn of man, belonging to the pre-primitive epoch dated in the end of the seventeenth century and the beginning of the eighteenth with the advent of the Industrial Revolution.

Darwin (1859), in one of his classics called "The origin of species", argues that the origin of humans is given from natural evolution with a historical development of nature's own natural imprint. For Darwin (1809-1889), man was taken away from Heaven to establish his roots on Earth, coming into existence bases for a new way to understand nature and man.

Therefore, since the birth of the first civilizations, there has been a strong and not always balanced presence of a relationship between society and nature. It must be considered that since the beginning of humanity, man has felt the necessity to live in group so that he could do a better planning of his actions/activities.

As a reinforcement to that thinking, Falcão Sobrinho et al (2017,p.115), in his reports, specifies that "the relationship between man and nature aimed subsistence". Given this fact, man has always sought to fulfill his necessities extracting from nature some resources originated from hunting, animal domestication and from fields with vegetation to cropping.

Consequently, with the increase of population density, it comes along a new organization of man called society what provided different conceptions until then not from man's reality. At last, society starts organizing itself to a new life system in which fighting for livelihood is not aimed anymore, but the increase of goods instead.

Thus, these differences are products for a new economic system (capitalism) which rises along with a new society's reorganization. Corresponding to such evolution stages in man's changes, or better, going from man to a social being, in each history moment, humanity has traced its view and meaning of nature. In Carvalho's work (1991, p.13), it is shown that:

In each one of these societies, or even in each of these times, nature possessed a different meaning according to values and objectives of each social grouping. So, for primitive societies,nature was not even recognized as something different from human grouping, once it was mistaken for the own life space of this grouping.

And he keeps saying:

For today's complex societies, it is not even possible to try to do a general characterization without jeopardizing the existing differences among their own components and, consequently, their different forms of perceiving the world [...] (CARVALHO, 1991, p.13).

From this position, it may be understood that the concept of nature is not natural, or rather, it is not only about nature be had as natural, but also about the view that it is created and constituted by men through their social relations, beliefs and interests, in short, the culture of a nation.

In that case, it happens because nature is the source for humans' livelihood through its resources exploitation in a degrading form and having, as consequence, some collateral damages, as stated by Newton's third law: "every action has a reaction".

Right after the eighteenth century, with the development of the Industrial Revolution, as previously reported, it may be said that society's impacts over the natural environment have been intensified in a never seen form and promoting series of factors which have boosted the generation of environmental impacts.

It is also worth mentioning that environmental impacts are consequences caused to the environment due to human actions, what may trigger several kinds of environmental degradation to physical environment components. To this end, in the $\operatorname{art}^{\circ} 1$ from theRegulation of the National Council of Environment (CONAMA) it is pointed out that environmental impact is any modification of physical, chemical and biological properties caused in a matter or energy form resulting from human actions which, directly or not, influence:

I -Population's health, security and welfare;

II - Social and economic activities;

III - Biota;

IV - Environment's aesthetical and sanitary conditions;

$\mathrm{V}$ - Environment resources quality;

However, Meruoca Sierra is held as a cutout for this research, place this which has been undergone modification processes in its natural scenery, (soil, relief, hydric resources and vegetation), reason this that makes it a region with natural potentiality. 
Upon this context, Falcão Sobrinho (1998) points out that elements that make up the nature deserve to be supported in the most varied resourcesmanners, being soil, vegetation, relief, climate and hydric resources, when they are intended for anthropogenic actions.

Moreover, there is also an exploitation in a social context, where it is possible to list the touristic activity which is highly attended by people from surrounding cities who looks for restaurants and hotels, often on holidays and weekends.

Faced to such situation, there is a worry since the attended places belong to the Environmental Protection Area - EPA, 2005. Regarding the creation of EPA, the article $\mathrm{n}^{\circ} 1$ states that the creation of such area aims to:

I - Guarantee the conservation of remaining deciduous and sub deciduous forests;

II - Protect Hydric Resources;

III - Protect wild fauna and flora;

IV - Promote the natural vegetation restoration;

V - Improve native population's life quality through guidance and discipline of local economic activities;

VI - Promote environmental education;

VII - Preserve local culture and tradition.

In article $\mathrm{n}^{\circ} 2$ in the law, Meruoca Sierra's EPA reveal the following boundaries: sector (I) and sector (II). To sector I: Northeast, East and Southeast side wrapping the own municipality of Meruoca and Massapê. As for sector II, it wraps Meruoca and Massapê too besides Alcântara and Sobral.

As for article $n^{\circ} 3$, there is an implementation and management of Meruoca Sierra's EPA, which applies specific measures.

What is more, in Meruoca Sierra's EPA, specifically in the article $n^{\circ} 4$ in the law, there are some criteria which restrain the following activities in this unity of conservation, namely:

I - Implementation of potentially polluting industrial activities which cause damages to environment or affect springs of water;

II - Activities which may boost erosion or siltation of hydric collections;

III - Activities which may kill, capture or bother regional biota rare species;

IV - The use of biocides and fertilizers, when it is indiscriminate or not in accordance to the official technical rules or recommendations;

$\mathrm{V}$ - Sand and rocky material removal of terrains which make up rivers and basins hillsides and provoke modifications in local ecological conditions.

\section{Meeting the study area}

Meruoca Sierra is in the Northwest side of Ceará, state this which according to Souza (2000, p.15) covers an area of $148.016 \mathrm{~km}^{2}$ between the coordinates $3^{\circ} 46^{\prime} 30^{\prime}$ and $7^{\circ} 52^{\prime} 54^{\prime}$ 'South latitude and $37^{\circ} 14^{\prime} 54^{\prime \prime}$ and $41^{\circ} 24^{\prime} 55^{\prime \prime}$ West longitude (Gr). It is $260 \mathrm{~km}$ far from Fortaleza and has as access path the highway BR-222. Considering its cartographical location, it is in the geographical coordinates $3^{\circ} 32^{\prime} 30^{\prime \prime}$ South latitude and $40^{\circ} 27^{\prime} 18^{\prime \prime}$ West longitude (Gr) and has an altitude of $670 \mathrm{~m}$.

It hassixcounties,namely Meruoca, Anil, Camilos, Palestina do Norte, Santo Antônio dos Fernandes and São Francisco. Furthermore, it covers an area of respectively $144,9 \mathrm{~km}^{2}$ and has an absolute population of 13.693 inhabitants (IPECE, 2017).

Out of this total, 7.420 are inhabitants from the urban area, representing 54,19\% of the absolute population (IPECE, 2017). About the rural area, there are 6.273 inhabitants representing $45,81 \%$ of the absolute population (IPECE, 2017). Image 01: MeruocaSierra - Rosário-CE Image 02:MeruocaSierra'sviewfrom Sobral -CE 


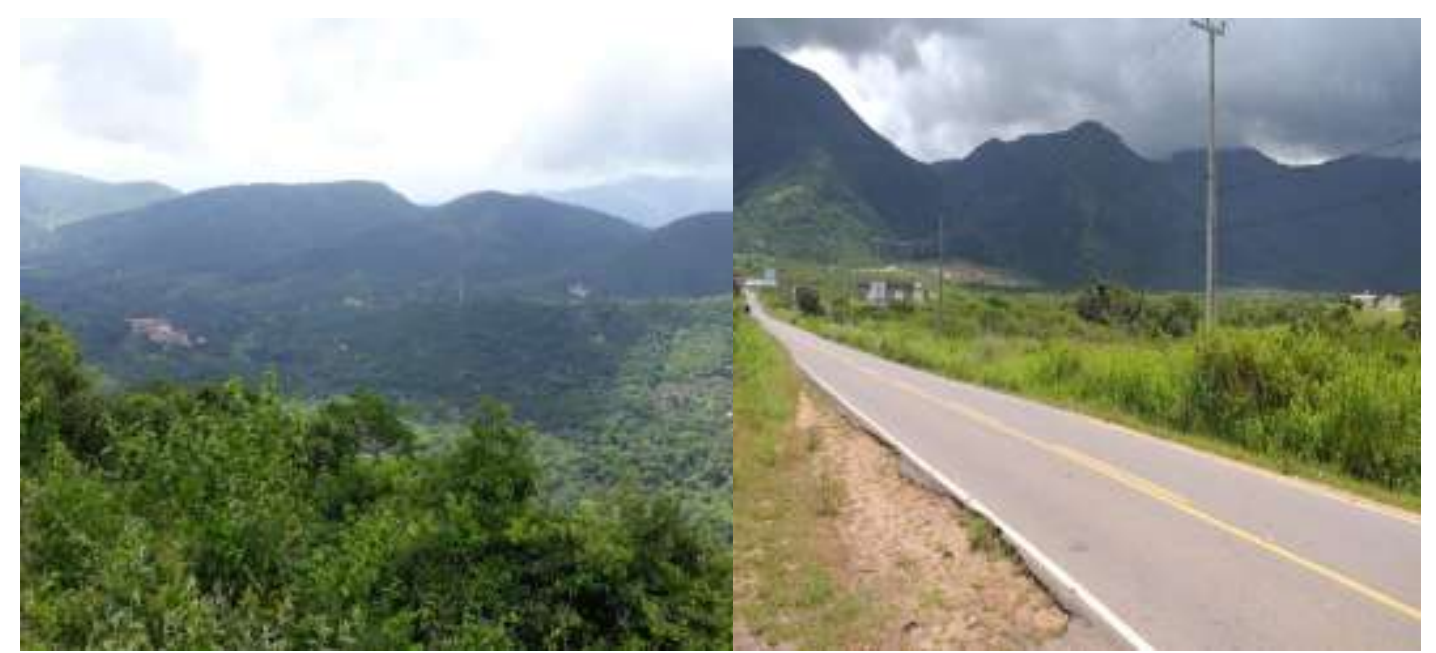

Source: MENDES (2019)Source: MENDES (2019)

It has as boundaries the following municipalities: Massapê to the North, Sobral to the South, Massapê to the East and Alcântara to the West (IPECE, 2017). Below is the cartographical product of the considered study area. Image 03: Location map of Meruoca Sierra's massif - CE

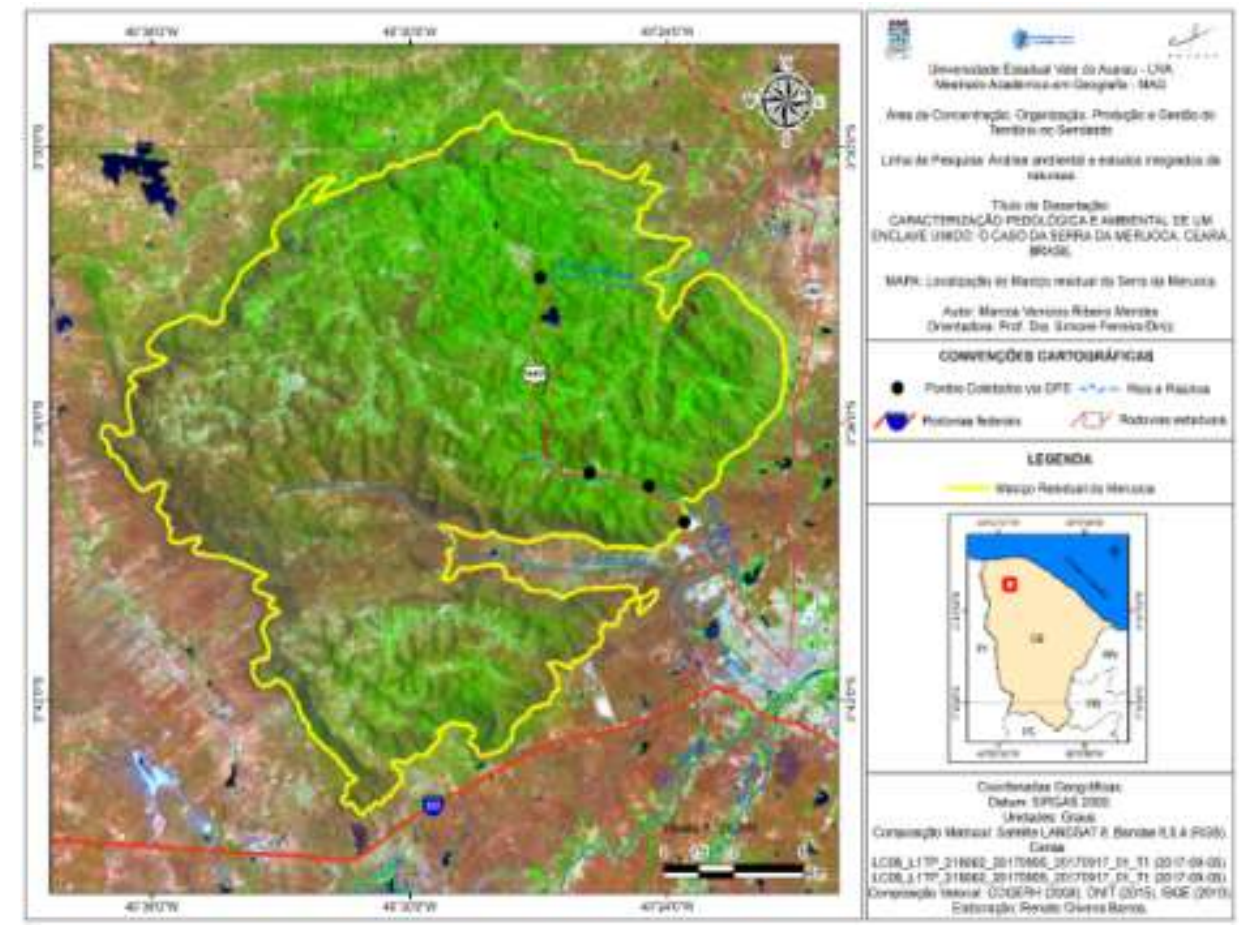

Source: BARROS; MENDES (2019)

\section{Study area description}

In the studied area, geological nature occurs principally by crystalline basement rocks which are made up of strongly resistant igneous or metamorphic rocks. Added to this fact, Meruoca Sierra is found inside the Borborema Orogenic System which corresponds to the Borborema province and covers a large part of the Northeast, being limited by Parnaíba basin to the West, São Francisco craton to the South, East Continental Margin to the East and Equatorial to the North (HASUI, 2012).

Regarding to its morphology, it is framed in the shields and old massif domains, fact this which can be observed through Ab Sáber's studies (2003) about nature and that portrays Brazilian morphoclimatic domains. With this, it is clearly understood that Meruoca Sierra is had as an exception area of humid enclave which Souza and Oliveira (2006) reinforce when expressed that such areas that are considered as humid and sub humid enclaves spread themselves in a scattered way throughout the semi-arid backcountry and are configured as true exception subspaces. 
As for the climate, it is the mild semi-arid hot tropical and sub humid hot tropical.Nevertheless, it presents conditions as a seasonal regional in association with tropical and subtropical belts (AB' SABER, 1974). In addition, Costa Falcão (2008, p.30) reports that this area creates a temperature microclimate which ranges from $297,15 \mathrm{~K}$ to $300,15 \mathrm{~K}$.

The average precipitation index in this environment stays most of the time around $1.000 \mathrm{~mm}$, varying from 950 and $1.000 \mathrm{~mm}$. Suffice to say, it provides denser vegetation such as seen in sub perennial tropical cloud forests, alias rainforests. In Fernandes' conception (1990), from 600-700m, it is delivered a perennial or sub perennial hygrophilous forest vegetation, included in altitude rainforests.

In view of that, there is the formation of deeper and more fertile soils, as it is the case of Red-Yellow Acrisol. For Diniz (2010), Red-Yellow Acrisol is a non-hydromorphic mineral soil with horizon A or E contiguous to not plinthic textural $\mathrm{B}$, clay of high or low activity and iron level less than $11 \%$. It is found in flat and little wavy relief areas (DINIZ, 2010).

Still considering soils, there is also the Neosol which is part of the pedological soil frame in Meruoca Sierra. About such soil category, it is pointed as "soils made up of mineral material or by a little thick organic material which do not present significant modifications regarding the original material due to the low intensity of pedogenetic processes activities[...] (EMBRAPA, 2006, p. 103)".It is noteworthy that the both kinds of soils that prevail in the area are RedYellow Acrisol and Neosol, which have already been introduced.

At last, the hydric resources, in which Meruoca Sierra establishes an important watershed, especially concerning Acaraú and Coreaú rivers (SOUZA; OLIVEIRA, 2006)which drain in Boqueirão and Contendas creeks. In what concerns surface water, the main actions to fight the drought effects are based principally on the construction of reservoirs, namelyJenipapo, Quebra, Padre and Freicheiras and Monte, standing out Jenipapo by being the hydric resource with the largest hydric disposition and being responsible to supply Meruoca and Alcântaras.

\section{Methodology}

In order to facilitate this work, it was adopted a methodological bias based initially on bibliographical analyses, which made able to portray the nature, incorporating its interactions to the society. On such occasion, it has been gone over the area natural frame, (relief, rocks, soils, vegetation, climate and hydric resources), what under the Ludvin Von Bertalanffy's theory (1975), it was sought to organize the ideas of system showing that parts would not be understood without the interaction of a whole, that is, interaction between nature and society.

Fieldworks directed to the studied area were carried out, situations in which GPS(Global Positioning System) was used to provide information about sites' location that delivered a support to develop the area cartographical material.

When it comes to the use of photography of the studied area, it was used a digital camera followed by observation and description of the use forms, occupation and their impacts on the environment affecting hydric resources, fauna, flora and principally soils which have been the most damaged natural resource by the improper practices imposed by society. For the purpose of understanding the relationship caused by society over nature in the studied environment, it was necessary to collect soil samples and for this reason it had been chosen two areas named (area I) and (area II). Through these choices, soils were collected to be physically analyzed, process which reveals sand, silt and clay levels with a textural category characterization.

Thus, the first collection was conducted in a preserved area, where Red-Yellow Acrisol prevails, and is placed in a most humid area in the following geographical coordinates: $3^{\circ} 32^{\prime} 49,602$ " South latitude and 40 26'59, 916" West longitude, having and altitude of $673,4 \mathrm{~m}$.

The second sample was a Neosol collected from a deforested area having the following geographical coordinates: $3^{\circ} 38^{\prime} 08,5^{\prime}$ 'South latitude $40^{\circ} 23 ’ 36,5^{\prime \prime}$ West longitude and an altitude of $210 \mathrm{~m}$.

Lastly, the gathering of information to deliver to deliver this work.

\section{Results and Discussion}

The desired result in this research revealed the nature dynamic in a social context, that is, modifications imposed by the society over the nature, modifying the exception environment of Meruoca Sierra. Parallel to modifications of natural elements, there is hydric resources pollution made through dejection thrown in water, considering that such hydric resources are sources to supply the population.

Mining is also another factor that causes damages over nature, happening when ore is taken out, consequently affecting fauna and flora. Another noticed impact was property speculation which has been occupying the Environmental Preservation Area - EPA and not respecting its laws. 
Consonant to soils, collections were carried out as previously described and soon after they were taken to an analysis laboratory.Such analyses were performed according to embrapa's recommendation contained on the Manual of Soil Analysis Methods (EMBRAPA, 2017).

For the purpose of physical analyses results, the following data are shared:

The Red-Yellow Acrisol sample is made up of altered material from granite. The sample results revealed rusted concretion, a dark red color, plastic material and stickiness. The area is used to produce ceramic production traded in the region. The environment is undefended, presenting a losing of its capability for agricultural production and liable to erosive processes amongst other serious problems.

In the analyzed sample, it was detected $47 \%$ of clay, factor which can make it be considered a clayey soil. Regarding to silt, $25 \%$, and to sand, a relevant level of $28 \%$, results which reveal a certain balance in relation to each soil fraction. Natural clay was found in a low level, that is, $1 \%$ which probably due to this soil is exposed and more vulnerable to environment changes.

With respect to Neosol sample, it comes from sandy deposits presenting a sandy or fine sandy texture. Moreover, it is made up essentially of quartz grains being therefore virtually devoid of primary minerals little resistant to weathering.

In such case, it was identified $>60 \%$ of sand, quartz presence in different colors and sizes, non-plastic, non-sticky, friable and vulnerable to erosive processes when it is not handled properly. The environment is undefended and submitted to erosion. The sample indicates $66 \%$ of sand, $19 \%$ of silt, $14 \%$ of clay and $2 \%$ of natural clay, being considered a sandy soil, susceptible to erosive processes with a considerable losing of soil. In brief, it may be stated that problems in Meruoca Sierra unleash damages unbalancing the natural ecosystem, specifically soils which have been quite exploited to agricultural uses.

\section{Final considerations}

Given all information, it may be understood that over the years, the use of work with tools has transformed the relationship nature-society process, breaking up with the natural standard of biologically established activities in which was held a demand of raw material extracted from nature. It is noticeable that, in Meruoca Sierra, environmental transformations are constant when it is about its natural elements, and the soil has been the most used due to be an area favorable to agricultural practices.

From agricultural practices held in an improper way, there is a loss of soils resulting in erosion, due to overlook relief's characteristics and restriction. Therefore, the consequence of such practice, in case, the erosive process is had as one of the biggest impacts which allows a loss of natural areas, reflex of alterations that society establishes over nature.

\section{Acknowledgments}

To FUNCAP by granting academic scholarships and to the Geography Mastership Program from Vale do Acaraú State University - CE - MAG/UVA.

\section{Bibliographic References}

AB'SÁBER, A.N. Semi-arid Morphoclimatic Domain in Brazilian Caatingas. Geomorphology, n. 43 IG- USP. São Paulo, 1974.

Nature Domains in Brazil:landscaped potentialities. São Paulo, SP: Ateliê Editorial, 2003.

BERTALANFFY, L. System General Theory. 2 ed. Petrópolis: Vozes, 1975.

CARVALHO, M.B. WhatisNature. $2^{\text {a }}$ ed., São Paulo: Brasiliense S. A., 1991.

COSTA FALCÃO, C, L. An Enclave Amidthe Northeast Semi-Arid: Meruoca Sierra Massif and the Use of the Land. In: COSTA FALCÃO, C. L; FALCÃO SOBRINHO, J; SOUSA, R. N. e MOTA, F. A. (Orgs). Semi-Arid: Natural and Cultural Diversities. Fortaleza, Expressão Gráfica, 2008, p. 187-202.

CONAMA. National Council of Environment (Brazil). Resolution $\mathrm{n}^{\circ}$ 001/ de 23/01/ 1996 Available on:<http://www.mma.gob.br>. Accessed onJuly 27, 2019.

DINIZ, S. F. Physiographicand Pedology Characterizationof the North Region in the State of Ceará. (PhD Thesis). Paulista State University, Rio Claro, 2010.

EMBRAPA. Soil Research National Center. Brazilian Soil Classification System. $2^{\text {nd }}$ edition, Rio de Janeiro-RJ, 2006. Manual of Soil Analysis Methods / Paulo César Teixeira ... [et al.], technicaleditors. $-3^{\text {rd }}$ ed. rev. e ampl. Brasília, DF: Embrapa, 2017.

FERNANDES, Afrânio. PhytogeographicTopics. Fortaleza: Stylos Comunicações, 1990 
FALCÃO SOBRINHO, J, 1998. The ModernizationofAgrarian Spaçe. [S.1.]: Essentia Magazine, p. 22 - 34. Physical Geography: NaturezainResearch and Teaching. Rio de Janeiro. TMAISOITO, 2008. ARAÚJO, ANA PAULA MARQUES; FALCÃO, ICARO LIMA COSTA; FALCÃO, ÍTALO LIMA COSTA. Nature, EnvironmentandTheSystem General TheoryEnvironmental, Economic e Legal Bases. HOLOS (NATAL ONLINE), v. 8, p. 104-125, 2017.

HASUI, Y.; CARNEIRO, C. D. R.; ALMEIDA, F. F. M.; BARTORELLI, A. 2012. $1^{\text {st }}$ edition. Brazilian Geology. Beca, São Paulo, pg. 254-288.

IPECE, Researchand Economic Strategy Instituteof Ceará. Fortaleza. 2017

SOUZA, M.J.N. Natural Bases and Outline of Ceará State Geoenvironmental Zoning. In: SOUZA, MORAES, J. O. LIMA, L.C. Territorial Compartmentation and Regional Management of Ceará, Part I. Fortaleza: FUNECE, 2000. 28-31p.

OLIVEIRA, V. P. V. Humid and Sub HumidEnclaves in Brazilian Northeast Semi-Arid. Mercator - UFC GeographyMagazine, year 05, $\mathrm{n}^{\circ}$ 09, 2006.

SILVA, A; CORREAA, A.C.B. The Relation Society-Nature: (R)ApproachmentofPhysical and Human Geography. Geography Magazine. Recife: UFPE - DCG/NAPA, v. 26, no 2, mai/ago. 2009. p. 111-123.

SILVA, F. E. R. The Conceptionof Nature under a Backcountry Comprehensionin Aracatiaçu Semi-Arid, Sobral-Ce. p.173. Thesis (Master's Degreein Geography) - Vale do Acaraú State University, Sobral, 2019. 